\title{
Conventional tillage versus organic farming in relation to soil organic carbon stock in olive groves in Mediterranean rangelands (southern Spain)
}

\author{
L. Parras-Alcántara and B. Lozano-García \\ Department of Agricultural Chemistry and Soil Science, Faculty of Science, Agrifood Campus of International Excellence - \\ ceiA3, University of Cordoba, 14071 Cordoba, Spain
}

Correspondence to: L. Parras-Alcántara (qe1paall@uco.es)

Received: 7 December 2013 - Published in Solid Earth Discuss.: 8 January 2014

Revised: 6 March 2014 - Accepted: 10 March 2014 - Published: 15 May 2014

\begin{abstract}
Soil organic carbon (SOC) concentration is a soil variable subject to changes. The management system is a key factor that influences these changes. To determine the long-term effects of the management system on SOC stocks (SOCS) in olive groves, 114 soil profiles were studied in the Los Pedroches Valley (Mediterranean rangelands - southern Spain) for 20 years. The management practices were conventional tillage (CT) and organic farming (OF) in four soil types: Cambisols (CMs), Regosols (RGs), Luvisols (LVs) and Leptosols (LPs). Soil properties were statistically analysed by management techniques, soil types and horizons. Significant differences $(p<0.05)$ were found between soil types and management practices. It was equally observed that the management system affected SOCS. In addition, the total SOCS during the 20-year experiment increased in OF with respect to CT by 72 and $66 \%$ in CMs and LVs respectively. SOC showed significant differences for horizons $(p<0.05)$ in relation to the management type. The stratification ratio (SR) was used as an indicator of soil quality based on the influence of surface SOC levels on erosion control, water infiltration and nutrient conservation with respect to deep layers. The SR of SOC from the surface to depth was greater in CT compared to OF with the exception of RGs. In all cases, the SR of SOC was $>2$. These results indicate high soil quality and that management practices affect SOC storage in the Los Pedroches Valley.
\end{abstract}

\section{Introduction}

Over the centuries, olive groves (OGs) have been a relevant social and economic heritage of Mediterranean areas. In Spain, the olive growing surface area is 2.58 million ha, increasing on average by $1-1.5 \%$ per year from 1995 to the present (ESYRCE, 2012). Subsidies and the rising price of olive oil have conditioned this growth (Louwagie et al., 2011). The olive oil production in Andalusia (Spain) is more than 1.3 million tonnes, constituting $85 \%$ of total Spanish production (MAGRAMA, 2012) and $41 \%$ of what is produced worldwide (IOC, 2012).

This activity has brought economic benefits to the region, but there have also been adverse effects. Olive production has traditionally been based on low tree density ( 100 trees ha $\left.{ }^{-1}\right)$, weeds being controlled by tillage and tree size limited by pruning (Álvarez et al., 2007). Traditionally, the management strategy has been conventional tillage (CT), marked by the frequent use of mouldboard ploughs, mineral fertilisation and herbicides. CT in OGs has caused a loss of soil quality with significant economic and environmental implications. CT has contributed to alterations in the nitrogen cycle (Fernández-Escobar et al., 2009), water loss by evaporation (Cerdà and Doerr, 2007), destruction of the soil structure (Gómez et al., 2009), loss of soil organic matter (SOM) and nutrients (Paustian et al., 2000) and high erosion rates (Calatrava et al., 2011). Traditional OG management has been associated with soil erosion (Castro et al., 2008), river and water body pollution (Colombo et al., 2005), degradation of landscape (Parra-López et al., 2009), and climate change (Rodríguez-Entrena et al., 2012). Besides, CT 
reduces soil fertility and OG production, increasing production costs (Calatrava-Leyva et al., 2007). This is particularly aggravated in Mediterranean climatic conditions (Gómez et al., 2009).

Recent studies show that the restriction on tillage (ParrasAlcántara et al., 2013a), and/or the addition of organic residues to soils (Lozano-García et al., 2011; Lozano-García and Parras-Alcántara, 2013a) may improve soil quality. Accordingly, organic farming (OF) may be an attractive option for reducing the soil degradation processes (Cerdà et al., 2010; Aranda et al., 2011).

In Mediterranean areas, the elements that affect soil carbon (C) variability are mainly climate (Wang et al., 2010), land use (Lozano-García and Parras-Alcántara, 2013b), management (Parras-Alcántara et al., 2013b, 2014a), slope and altitude (Hontoria et al., 2004; Lozano-García and ParrasAlcántara, 2014), tillage intensity and no-till duration (Conant et al., 2007). Of all these factors, soil management is the best tool for climate change mitigation and adaptation (Lal et al., 2011). Over time, some researchers have studied the relationship between soil management effects in OGs and C capture and storage in soils as soil organic carbon (SOC) (ParrasAlcántara et al., 2013a, b; Romanya and Rovira, 2011). However, many of these studies have evaluated SOC content on the soil surface, whereas only a few studies have included deeper soil sections. In Mediterranean areas, SOC can be stored in deep layers (below $30 \mathrm{~cm}$ deep). This is important in OF, as SOC can be transported to deeper soil horizons, contributing to the subsoil C storage (Lorenz and Lal, 2005).

Climatic conditions in Mediterranean areas are limiting factors that affect accumulation of SOC. Thus, SOC determination might not be the best indicator of the improvement caused by management, as mineralisation rates vary with depth. Under these conditions, it may be more interesting to consider the stratification ratio (SR) of SOC (CorralFernández et al., 2013). The use of the SR as a soil quality indicator is based on the influence of surface SOC levels on erosion control, water infiltration and nutrient conservation (Franzluebbers, 2002). High SOC and nitrogen (N) SR values reflect undisturbed soil and high soil quality of the surface layer. The SR growth can be related to the rate and amount of SOC sequestration. However, ratios $<2$ are frequent in degraded soils (Franzluebbers, 2002).

Very limited information is available regarding OF effects under semi-arid Mediterranean conditions in organic OGs. Consequently, the aims of this study were: (i) to determine the soil properties that affect soil development in the Los Pedroches Valley (OG in Mediterranean rangelands - southern Spain), (ii) to study the vertical distribution of SOC stock under two management practices (CT and $\mathrm{OF}$ ) and (iii) to analyse the soil variables that are involved in the SR of SOC in OG using traditional and organic management systems in entire soil profiles.

\section{Material and methods}

\subsection{Study site and management type}

The study area is located in the Los Pedroches Valley (Cordoba, southern Spain), between 38.39 and $37.15^{\circ} \mathrm{N}, 4.50$ and $4.15^{\circ} \mathrm{W}$ (Fig. 1) and comprises 10600 ha where the dominant land use is $\mathrm{OG}$. The average annual temperature is $16^{\circ} \mathrm{C}$ and the annual thermal amplitude ranges from $-2{ }^{\circ} \mathrm{C}$ in winter to $40^{\circ} \mathrm{C}$ in summer. The study area is characterised by cold winters and warm summers, and the average annual rainfall is $600 \mathrm{~mm}$. The climate is temperate semiarid Mediterranean with continental influence. The moisture regime is dry Mediterranean. High temperatures and long drought periods cause water deficits up to $400 \mathrm{~mm}$ per year. The relief is smooth, with slopes ranging from 1 to $4 \%$, and the parent material is granite. According to IUSS Working Group WRB (2006), the most abundant soils are Cambisols (CMs), Luvisols (LVs), Regosols (RGs) and Leptosols (LPs).

Two soil management practices were selected for this study: OF and CT in four soil types (CMs, LVs, RGs and LPs). The OF were under this practice for 20 years (19892009), with no synthetic mineral fertilisation or pesticides and untilled soils. In these, the vegetative cover is kept under control by mowing from early to late spring with animal manure incorporation. $\mathrm{CT}$ is characterised by three ploughs per year at a depth of $15-20 \mathrm{~cm}$ from early spring (disk harrow and cultivator) to early autumn (tine harrow), weed control with residual herbicides, and annual application of ammonium sulphate $\left(250 \mathrm{~kg} \mathrm{ha}^{-1}\right)$. Moreover, two applications of foliar fertilisation per year were performed in $\mathrm{CT}$, in spring $\left(0.3 \mathrm{~kg}\right.$ amino acids ha ${ }^{-1}, 0.7 \mathrm{~kg} \mathrm{Nha}^{-1}, 0.4 \mathrm{~kg} \mathrm{Pha}^{-1}$ and

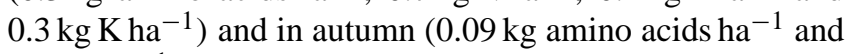
$\left.1 \mathrm{~kg} \mathrm{Kha}{ }^{-1}\right)$.

In all cases (soil types and management practices), the average density of Olea europaea spp. europaea in OG is 100 110 trees ha $^{-1}$. Forty-year old olive trees, spaced $10 \times 10 \mathrm{~m}$, were selected for the study.

\subsection{Soil sampling and analyses}

Soil samples (entire profiles: 50 in CMs, 20 in LVs, 28 in LPs and 16 in RGs) were collected according to FAO (2006) in a random sample design (representative of the whole study zone): 70 samples in CT and 44 samples in OF (114 profiles $\times 3$ or 2 horizons $\times 4$ replicated) in the Los Pedroches Valley in 2009 in OG. We have selected fewer soil profiles in OF because the study area was smaller than the study area in CT. Soil entire profiles were collected in open areas.

Soil samples were air-dried at a constant room temperature $\left(25^{\circ} \mathrm{C}\right)$ and sieved $(2 \mathrm{~mm})$ to remove coarse soil particles. Four replicates of each sample were analysed in the laboratory to reduce the experimental error. Analytical methods and others parameters calculated are described in Table 1. 
Table 1. Methods used in field measurements, laboratory analysis and calculated from field data.

\begin{tabular}{|c|c|}
\hline Parameters & Method \\
\hline $\begin{array}{l}\text { Field measurements } \\
\text { Bulk density }\left(\mathrm{Mg} \mathrm{m}^{-3}\right)\end{array}$ & Cylindrical core sampler* (Blake and Hartge, 1986) \\
\hline 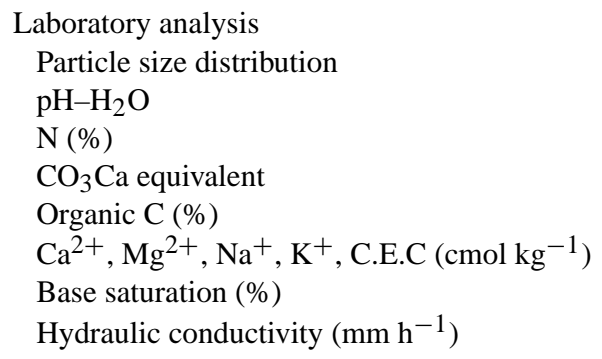 & $\begin{array}{l}\text { Robinson pipette method (USDA, 2004)** } \\
1: 2.5 \text { suspension in water (Guitián and Carballas, 1976) } \\
\text { Kjeldahl method (Bremner, 1996) } \\
\text { Volumetric with Bernard calcimeter (Duchaufour, 1975) } \\
\text { Walkley and Black method (Nelson and Sommers, 1982) } \\
\text { (Bower et al., 1952) } \\
\text { (Duchaufour, 1975) } \\
\text { Mono-disc multiple potential process (Reynolds and Elrick, 1991) }\end{array}$ \\
\hline $\begin{array}{l}\text { Parameters calculated from field data } \\
\mathrm{C}: \mathrm{N} \text { ratio } \\
\text { SOC stock }\left(\mathrm{Mg} \mathrm{ha}^{-1}\right) \\
\text { Total SOC stock }\left(\mathrm{Mg} \mathrm{ha}^{-1}\right) \\
\text { SR }\end{array}$ & $\begin{array}{l}\text { Ratio of organic C to organic } \mathrm{N} \\
\left(\mathrm{SOC} \text { concentration } \times \mathrm{BD} \times \mathrm{d} \times\left(1-\delta_{2} \mathrm{~mm} \%\right) \times 0.1\right)^{* * *}(\text { Wang and Dalal, 2006) } \\
\Sigma_{\text {horizons }} \text { SOC Stock } k_{\text {horizon }}(\mathrm{IPCC}, 2003) \\
(\text { SOC-Ap onto SOC-Bw/C) }\end{array}$ \\
\hline $\begin{array}{l}\text { ** Where SOC is the organic carbon content }\left(\mathrm{g} \mathrm{kg}^{-1}\right), \mathrm{d} \text { th } \\
\text { the soil, and BD the soil bulk density }\left(\mathrm{Mg} \mathrm{m}^{-3}\right) \text {. } \\
\text { y*** The SR is defined as a soil property on the soil surface }\end{array}$ & $\begin{array}{l}\text { reated with } \mathrm{H}_{2} \mathrm{O}_{2}(6 \%) \text { to remove organic matter }(\mathrm{OM}) \text {. Particles larger than } 2 \mathrm{~mm} \text { were determined by } \\
\text { standards }(2004) \text {. } \\
\text { hess of the soil layer }(\mathrm{cm}), \delta_{2} \mathrm{~mm} \text { is the fractional percentage (\%) of soil mineral particles }>2 \mathrm{~mm} \text { in size } \\
\text { by the same property at a lower depth. In this study, we defined two SRs for the CM and LV [SR1 } \\
\text { /C)]. }\end{array}$ \\
\hline
\end{tabular}

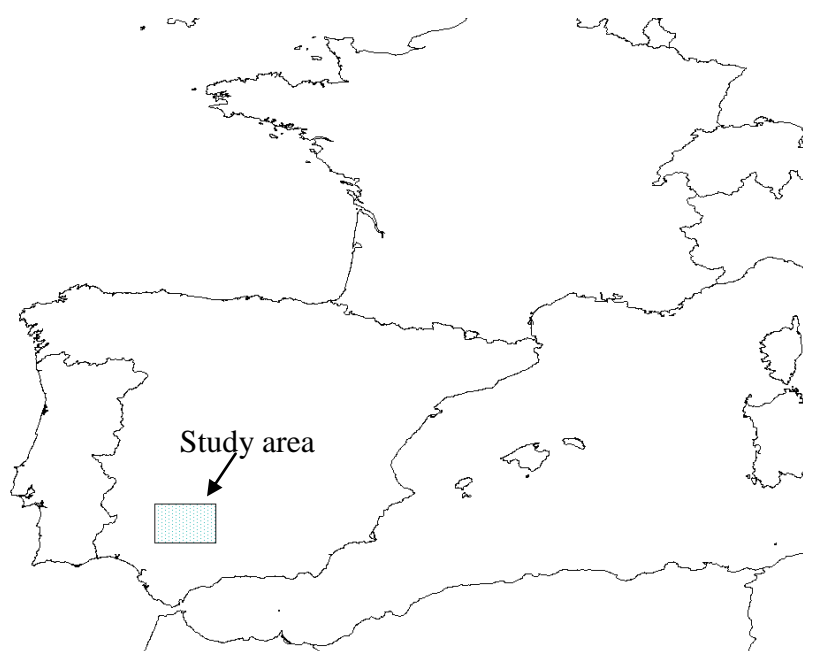

Fig. 1. Study area.

\subsection{Statistical analysis}

A statistical analysis for each management system was applied to evaluate the physical and chemical horizon properties. Pearson's correlation coefficients were carried out to understand the relationships between different parameters (physical and chemical). An analysis of variance (ANOVA) was carried out to determine the importance of three sources of variability (main factors): soil type (CMs, LVs, LPs and
RGs), soil management (CT and OF), and horizons (Ap-h, $\mathrm{Bw}-\mathrm{t}$ and $\mathrm{C}$ ) and their interactions. Significant differences were deemed statistically relevant from the Turkey test was used to compare the results, with significant differences considered at $p<0.05$. A principal component analysis (PCA) was performed to minimise and explain the variability of the system; only the eigenvalues $>0.3$ were considered for PCA interpretation. The Anderson-Darling normality test was used to check the normal distribution of SR. All calculations, including statistical analysis, were computed using the Minitab software package (Minitab, 2000).

\section{Results and discussion}

\subsection{Soil properties and principal components analyses}

The studied soils were CMs, LPs, RGs and LVs (IUSSISRIC-FAO, 2006). Data for the soil profiles are compiled in Table 2. The soils in the Los Pedroches Valley are conditioned by lithology (granite) and the formation processes of these soils take place with low slope (Nerger et al., 2007), thus they are shallow soils (Marañón, 1988).

LVs are fertile soils that are suitable for a wide range of Mediterranean crops such as cereals, fruit trees, olives and vineyards (Zdruli et al., 2011). The principal characteristic of these soils is a high clay content in the subsoil (CTLVs-Bt: $39.6 \%$; OF-LVs-Bt: $30.2 \%$ ) compared to the topsoil 


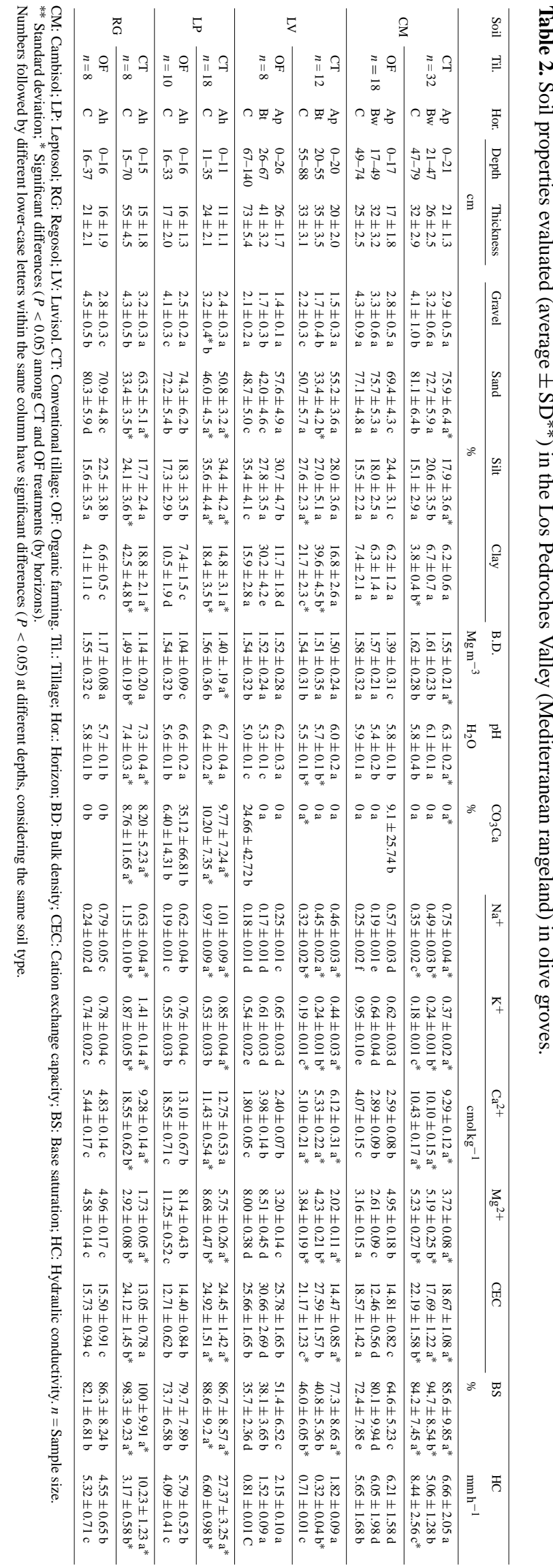

(CT-LVs-Ap: $16.8 \%$; OF-LVs-Ap: $11.7 \%$ ) as a result of pedogenetic processes (clay migration - leading to an argillic subsoil horizon). An important feature of these soils is the low OM content (González and Candás, 2004). This is justified by climatic conditions (semi-arid Mediterranean) and soil texture (sandy soils), which contribute to a low organic matter content (Parras-Alcántara et al., 2013b, 2014b). With respect to CMs, RGs and LPs, these soils are characterised by low fertility, poor physical conditions and a marginal capacity for agricultural uses. CMs are then more developed than RGs and LPs. LPs are the less developed soils, influenced by topography and physiographic location (Recio et al., 1986).

Normally, the studied soils had an acid $\mathrm{pH}(5.3-6.7)$ and moderated or saturated base saturation (BS) (100-77.3\%), mainly calcium. With regard to $\mathrm{N}$ concentrations, these were lower in CMs and LVs (0.13\% A horizon in CMs-OF; $0.02 \%$ B horizon in LVs-CT). Another important characteristic was a decrease in nutrient content with depth. Also, the sand proportion was higher in LVs, RGs and LPs under OF than in soils under CT. However, an opposite trend (more in $\mathrm{CT}$ than $\mathrm{OF}$ ) was observed for clay content, $\mathrm{pH}$, BS and hydraulic conductivity (HC). The CEC was high, ranging from $12.45 \mathrm{cmol} \mathrm{kg}^{-1}$ to $30.66 \mathrm{cmol} \mathrm{kg}^{-1}$ (limit proposed by Hazelton and Murphy, 2007 based on Metson, 1961). In this line, Ruiz et al. (2012) in Mediterranean rangelands obtained similar results, while Pulido-Fernández et al. (2013) in Iberian open woodland rangelands obtained low CEC values caused by nutrient scarcity. SOC content was generally low in all the studied soils, although the SOC decrease with depth was much more intense in CT soils. The higher SOC content in topsoil in OF could be attributed to the management type, which increases the soil vegetative cover and maximises the organic residue transfer. Also, it reduced the soil erosion risk. Similar results were obtained by CorralFernández et al. (2013) for evergreen oak woodland with OF in the Los Pedroches Valley. In that context, OF can be regarded as a key factor to take into account when considering environment-friendly management practices (HathawayJenkins et al., 2011). The carbon-nitrogen $(\mathrm{C}: \mathrm{N})$ ratio suggested generally suitable conditions for active microbial development and humus recycling (Tables 2 and 3).

Factors affecting soil development in the study area were predominantly parameters related to the soil chemical properties and, to a lesser degree, chemical parameters. Numerous significant linear correlations were found among soil properties using Pearson's correlation matrix (Table 4). Some related variables were SOC and N, sand and clay content, and sand and silt content with an extremely strong correlation ( $p<0.001 ; r=0.997, r=-0.810, r=-0.753$ respectively). Other significant relations were exchangeable $\mathrm{Mg}^{2+}$ and CEC, exchangeable $\mathrm{Ca}^{2+}$ and $\mathrm{CEC}, \mathrm{SOC}$ and $\mathrm{C}: \mathrm{N}$ ratio with a strong correlation $(p<0.001 ; r=0.662, r=0.629$ and $r=0.624$ respectively). Since extremely strong and strong correlations were found (Table 4), PCA was necessary to identify critical factors determining soil development in the 


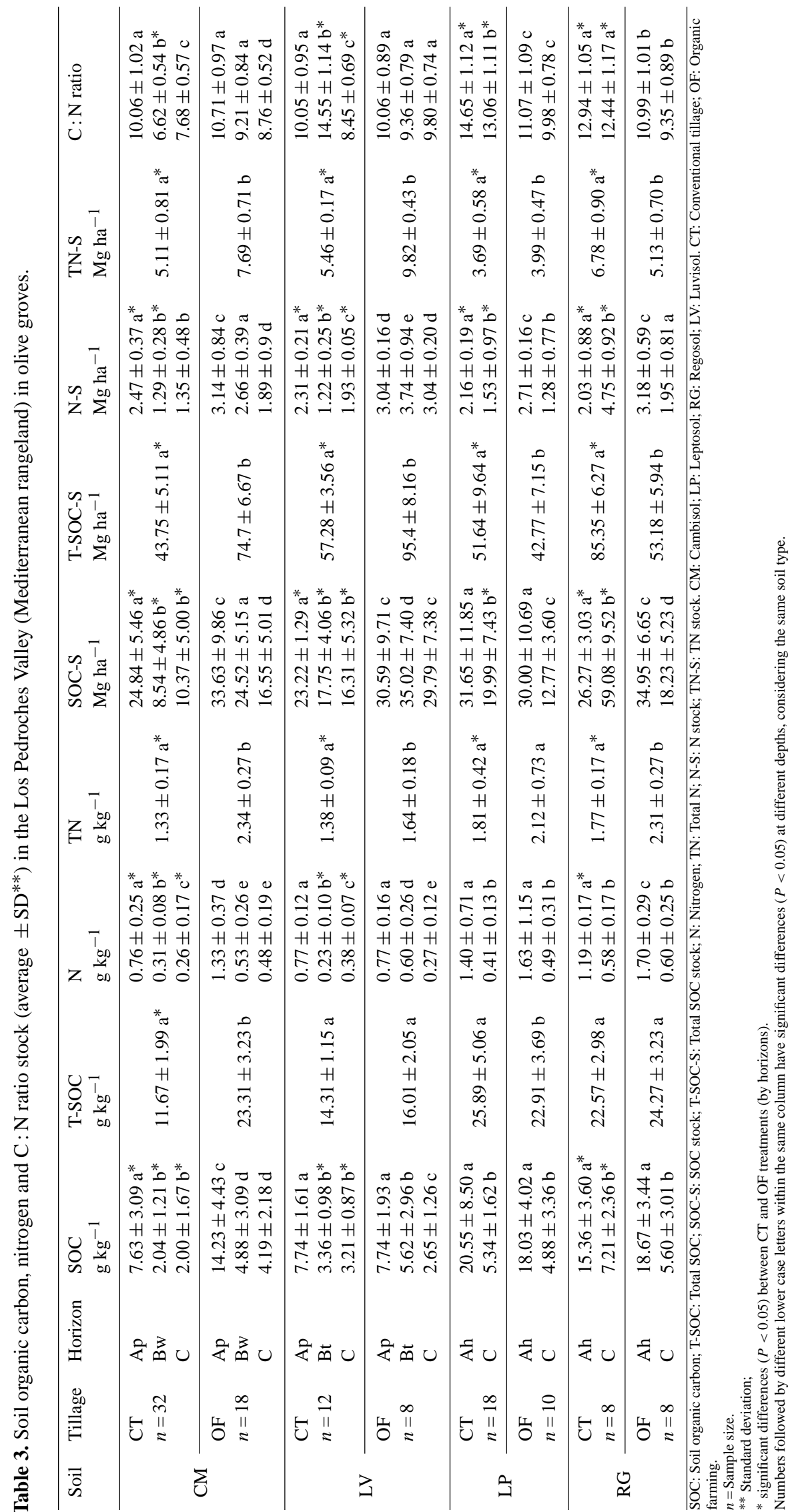




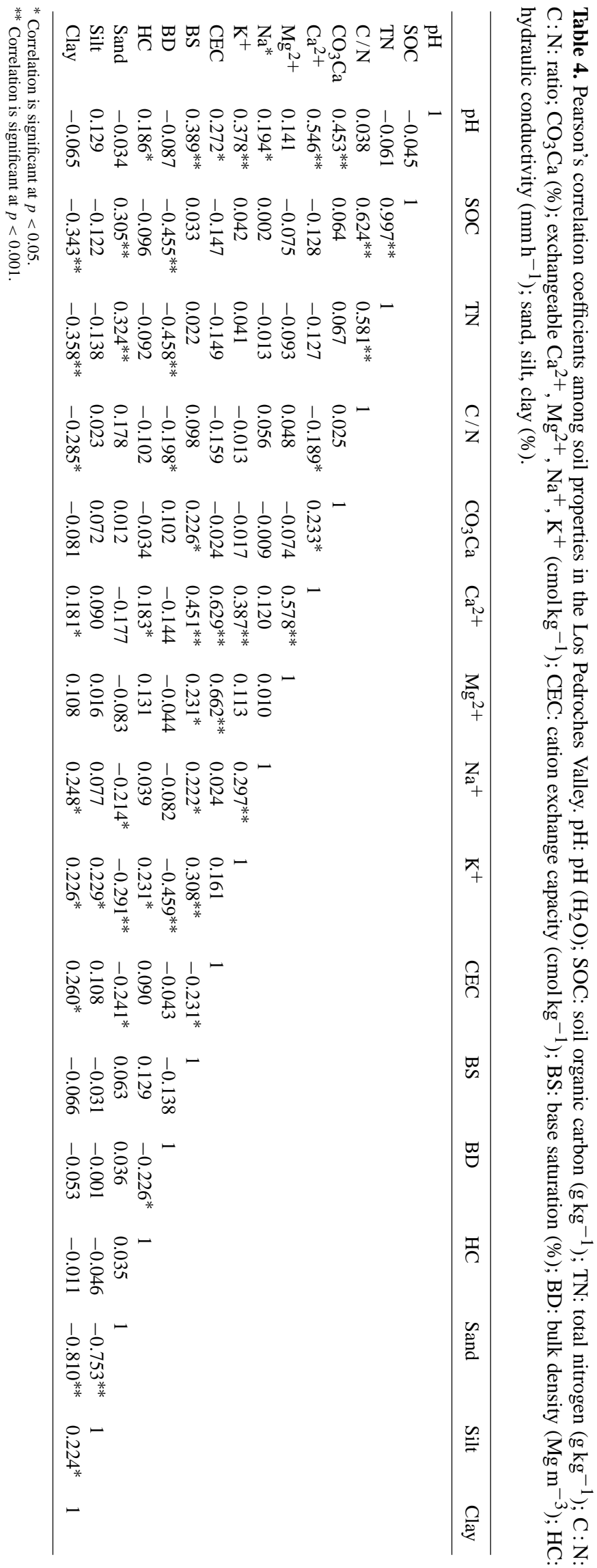

Los Pedroches Valley using PCA. Fifteen physical and chemical soil properties were included in the PCA, and four factors (eigenvalue $>3$ ) were identified (Table 5). Considering average data for each soil properties, thirteen properties were found that account for $65 \%$ of the variance. PCA explained $22.5,19.9,13.3$ and $9.3 \%$ of the variance from PC1, PC2, PC3 and PC4 respectively. Factor PC1 is positively correlated with exchangeable $\mathrm{K}^{+}$and $\mathrm{Ca}^{2+}$, BD and SOC. This factor mostly groups parameters related to soil chemical conditions. PC2 received the greatest loading from sand content, clay content and thickness. All resulted as negative except sand content, grouping parameters related to the soil physical condition. PC3 grouped parameters related to the soil chemical condition (exchangeable $\mathrm{Ca}^{2+}$, exchangeable $\mathrm{Mg}^{2+}$ and CEC); all with positive performance. Finally, PC4 grouped $\mathrm{C}: \mathrm{N}$ ratio, exchangeable $\mathrm{Na}^{+}, \mathrm{BS}$ and $\mathrm{HC}$; all positive except $\mathrm{C}: \mathrm{N}$ ratio (Table 5). As regards soil chemical properties, soils are defined by the dominance of basic cations, conditioned by lithology (Recio et al., 1986) and carbonates, especially in RGs and LPs. According to this, Nerger et al. (2007), in his study in the Los Pedroches Valley, justify the high influence of chemical properties caused by carbonate presence (high $\mathrm{Ca}^{2+}$, basic $\mathrm{pH}$ and low $\mathrm{OM}$ in the top soil) that could affect soil development. In addition, the $\mathrm{Ca}^{2+}$ enrichment could be related to the continental influence (ion enrichment in the soil solution) due to climatic conditions (high rainfall in certain seasons). However, high tree density may affect SOC content (González et al., 2012). This is in agreement with our data (high nutrient contents and high CEC) compared with other Mediterranean rangelands. The PCA results showed that sand content (PC2) is a key factor that may affect soil development in the Los Pedroches Valley. In accordance with this, Hontoria et al. (2004) suggested that variables affecting soil development in the driest areas of Spain are those related to the specific texture more than those related to management or climate. Moreover, Castro et al. (2008) reported that soil texture is the first property that influences SOC in agricultural soils.

The ANOVA for PCA (horizons, soil type and management) showed that there were significant differences $(p<$ 0.001 ) between soil types for PC2, related to physical and chemical properties. Also, when the management system was analysed, significant differences were found in PC1 $(p<0.001), \operatorname{PC} 2(p<0.05)$ and PC3 $(p<0.05)$, influenced principally by physical properties (Table 6 ). In the case of the horizon type, significant differences were found in PC1 $(p<0.001)$ and PC2 $(p<0.05)$ caused by thickness, SOC, $\mathrm{N}$, BD, clay and $\mathrm{K}^{+}$(Table 6). However, when total SOC was analysed, no significant differences related to the management system were found in LVs, LPs and RGs. In this line, Parras-Alcántara et al. (2014b) indicates that OF has little effect on carbon stock in Mediterranean dehesa. Also, Bradford and Peterson's (2000) study assessing various land uses indicates that sometimes there is no difference between conventional, minimum, or reduced tillage. 
Table 5. Ordinary components for the principal component analysis (PCA) of selected soil properties measured for all the soil types grouped*.

\begin{tabular}{|c|c|c|c|c|}
\hline Variable or factor & PC1 & $\mathrm{PC} 2$ & $\mathrm{PC} 3$ & PC4 \\
\hline Thickness (cm) & -0.155 & -0.303 & 0.023 & -0.062 \\
\hline $\mathrm{BD}\left(\mathrm{g} \mathrm{cm}^{-3}\right)$ & $\underline{0.385}$ & 0.167 & 0.222 & 0.108 \\
\hline $\mathrm{SOC}\left(\mathrm{g} \mathrm{kg}^{-1}\right)$ & $\overline{0.380}$ & 0.255 & -0.214 & 0.025 \\
\hline $\mathrm{C} / \mathrm{N}$ & $\overline{0.058}$ & 0.287 & -0.054 & -0.428 \\
\hline $\mathrm{pH}\left(\mathrm{H}_{2} \mathrm{O}\right)$ & 0.277 & 0.026 & 0.215 & $\overline{0.061}$ \\
\hline $\mathrm{Ca}^{2+}\left(\mathrm{cmol} \mathrm{kg}^{-1}\right)$ & 0.302 & -0.083 & 0.485 & 0.070 \\
\hline $\mathrm{Na}^{+}\left(\mathrm{cmol} \mathrm{kg}^{-1}\right)$ & 0.211 & -0.031 & $-\overline{0.108}$ & 0.365 \\
\hline $\mathrm{Mg}^{2+}\left(\mathrm{cmol} \mathrm{kg}^{-1}\right)$ & 0.153 & -0.073 & 0.489 & $-\overline{0.234}$ \\
\hline $\mathrm{K}^{+}\left(\mathrm{cmol} \mathrm{kg}^{-1}\right)$ & 0.419 & 0.103 & $-\overline{0.083}$ & 0.168 \\
\hline $\mathrm{CEC}\left(\mathrm{cmol} \mathrm{kg}^{-1}\right)$ & 0.237 & -0.276 & 0.364 & -0.260 \\
\hline $\mathrm{BS}(\%)$ & 0.023 & 0.286 & $\overline{0.252}$ & $\underline{0.350}$ \\
\hline $\mathrm{HC}\left(\mathrm{mm} \mathrm{h}^{-1}\right)$ & 0.170 & 0.181 & 0.083 & $\overline{0.380}$ \\
\hline Sand $(\%)$ & -0.260 & $\underline{0.414}$ & 0.241 & 0.034 \\
\hline Silt $(\%)$ & 0.271 & $-\overline{0.271}$ & -0.170 & -0.287 \\
\hline Clay $(\%)$ & 0.158 & -0.407 & -0.225 & 0.222 \\
\hline Eigenvalues & 3.608 & 3.178 & 2.135 & 1.494 \\
\hline$\%$ variance & 22.5 & 19.9 & 13.3 & 9.3 \\
\hline $\begin{array}{l}\text { Cumulative } \\
\text { explanation }\end{array}$ & 22.5 & 42.4 & 55.8 & 65.1 \\
\hline
\end{tabular}

SOC: soil organic carbon; exchangeable $\mathrm{Ca}^{2+}, \mathrm{Mg}^{2+}, \mathrm{Na}^{+}, \mathrm{K}^{+} ; \mathrm{CEC}$ : cation exchange capacity; BS: base saturation (\%); BD: bulk density; HC: hydraulic conductivity.

$*$ Variables underlined with eigenvectors (coefficients) $>0.3$ are considered significant.

\subsection{Soil organic carbon, nitrogen and $\mathrm{C}: \mathrm{N}$ ratio}

SOC and $\mathrm{N}$ concentrations decreased with depth (Table 3). SOC and $\mathrm{N}$ content increased in the A horizon from $\mathrm{OF}$ to $\mathrm{CT}$ in all soil types except the Ah horizon in LPs for SOC (20.55 $\mathrm{g} \mathrm{kg}^{-1} \mathrm{CT} ; 18.03 \mathrm{~g} \mathrm{~kg}^{-1} \mathrm{OF}$ ). Castro et al. (2008) observed a similar trend at different depths in soils with OGs. As for the surface horizons, SOC values were highly heterogeneous, ranging from $20.55 \mathrm{~g} \mathrm{~kg}^{-1}$ to $7.63 \mathrm{~g} \mathrm{~kg}^{-1}$ for LPs$\mathrm{CT}$ and CMs-CT respectively. $\mathrm{N}$ had a similar trend, ranging from $1.70 \mathrm{~g} \mathrm{~kg}^{-1}$ to $0.76 \mathrm{~g} \mathrm{~kg}^{-1}$ (RGs-OF; CMs-CT). Normally, high SOC values involved high $\mathrm{N}$ values. The SOC in CT was $<10 \mathrm{~g} \mathrm{~kg}^{-1}$ with the LPs exception in Ap horizons $\left(20.55 \mathrm{~g} \mathrm{~kg}^{-1}\right)$. Conversely, SOC was higher $\left(>10 \mathrm{~g} \mathrm{~kg}^{-1}\right)$ in OF for all soils. In this line, Bronick and Lal (2005), explain that CT (low OM inputs, ploughing and low vegetation cover) in OGs limits the incorporation of organic residues and enhances soil erosion risk. Also, the formation process between $\mathrm{OM}$ and mineral aggregates diminishes in the surface horizons in sandy soils (González and Candás, 2004). This justifies high levels of transformed OM and explains low OM concentrations at greater depths in the studied soils. In this sense, López-Garrido et al. (2011) observed similar results for different crops and management systems. Besides, Franzluebbers (2005) concludes that the topsoil is more vul- nerable to changes in management practices, and the carbon sequestration occurs principally in the upper horizons. However, the surface horizon is not the layer with the higher SOC sequestration potential because SOC exists in stable forms in depth, which makes it highly recalcitrant to biodegradation processes (Lorenz and Lal, 2005). Nevertheless, CT promotes a fast SOM mineralisation in Mediterranean agricultural soils (Melero et al., 2009).

With regard to the management system, SOC and $\mathrm{N}$ showed significant differences $(p<0.05)$ in all horizons for CMs, LPs and RGs (Table 3 ). In the case of total SOC content, significant differences $(p<0.05)$ were only found in CMs. However, when total $\mathrm{N}$ was analysed, significant differences $(p<0.05)$ were found for management types in all cases. The $\mathrm{C}: \mathrm{N}$ ratio at the surface compared to that in depth was generally higher in OF compared to CT. This coincides with Blanco-Canqui and Lal (2008) and could be explained by the higher contribution of residue input on the surface under OF compared to CT. Also, this may reflect less OM decomposed in the soil surface in OF. Additionally, the residue retention can increase SOC (Xu et al., 2011) with lower decomposition degree and higher $\mathrm{C}: \mathrm{N}$ ratio (Yamashita et al., 2006). The $\mathrm{C}: \mathrm{N}$ ratio tended to decrease with depth in CMs, LPs and RGs under OF. However, an opposite trend was observed (increase in the $\mathrm{C}: \mathrm{N}$ ratio with depth) in CMs and LVs in CT. In this sense, Diekow et al. (2005) and Yamashita et al. (2006) explained that this decrease with depth could be associated with clay content (that increased with depth). High clay levels are associated with high decomposed OM and a lower $\mathrm{C}: \mathrm{N}$ ratio (Diekow et al., 2005; Yamashita et al., 2006). On the other hand, an opposite trend was observed in soils under CT, which may be attributed to high $\mathrm{C}: \mathrm{N}$ soluble organic compounds leaching into deeper layers (Diekow et al., 2005).

SOC had strong positive correlations (Table 4$)(p<0.001)$ with $\mathrm{N}(r=0.997)$ and $\mathrm{C} / \mathrm{N}$ ratios $(r=0.624)$. A similar trend was observed with respect to $\mathrm{BD}$, but in this case the correlation was negative $(r=-0.455)$; when SOC increased, BD decreased. However, when thickness horizon increased, SOC was scattered and was likely to have underwent a redistribution process. Other small correlations $(p<0.001)$ were observed for sand content $(r=0.305)$ and clay content $(r=-0.343)$. Similarly, correlations between SOC and other soil parameters in the surface horizon were found. SOC was strongly correlated with $\mathrm{N}$ clay content and exchangeable $\mathrm{Na}^{+}(r=0.999, p=0.000$; $r=-0.350, p=0.008 ; r=-0.342, p=0.009)$. In addition to this, SOC was moderately correlated with sand content and exchangeable $\mathrm{K}^{+}$and $\mathrm{Ca}^{2+}(r=0.263, p=0.048$; $r=-0.334, p=0.011 ; r=-0.279, p=0.036)$. This correlates with the results of Hontoria et al. (2004), which suggest that the variables that affect soil development in the driest areas of Spain the most are physical variables, rather than the management or climatic ones. SOC and N content was higher in the surface horizons for CMs and LVs in OF with 
Table 6. General lineal model (GLM). ANOVA (soil type and management) for soil. Statistical analyses of soil were carried out for A horizon samples $(r$ coefficient).

\begin{tabular}{|c|c|c|c|c|c|c|}
\hline \multicolumn{7}{|c|}{ One-way ANOVA } \\
\hline \multirow[b]{2}{*}{ Parameter } & \multicolumn{3}{|c|}{ Soil-type management } & \multicolumn{3}{|c|}{ Management horizon } \\
\hline & $\mathrm{S}$ & M & $\mathrm{S} \times \mathrm{M}$ & M & $\mathrm{H}$ & $\mathrm{M} \times \mathrm{H}$ \\
\hline $\mathrm{Th}$ & 0.227 & 0.713 & $0.012^{*}$ & 0.713 & $0.000^{* * *}$ & 0.888 \\
\hline $\mathrm{pH}$ & $0.028^{*}$ & 0.397 & $0.010^{* *}$ & 0.397 & $0.002^{* *}$ & 0.151 \\
\hline SOC & 0.727 & $0.000^{* * *}$ & $0.003^{* *}$ & $0.000^{* * *}$ & $0.000^{* * *}$ & $0.007^{* *}$ \\
\hline $\mathrm{TN}$ & 0.452 & $0.000^{* * *}$ & $0.001^{* * *}$ & $0.000^{* * *}$ & $0.000^{* * *}$ & $0.008^{* *}$ \\
\hline $\mathrm{C} / \mathrm{N}$ & $0.001^{* * *}$ & 0.370 & $0.002^{* *}$ & 0.370 & 0.070 & $0.043^{*}$ \\
\hline $\mathrm{Ca}^{2+}$ & 0.239 & 0.083 & 0.149 & 0.083 & 0.214 & 0.881 \\
\hline $\mathrm{Mg}^{2+}$ & 0.832 & 0.132 & 0.177 & 0.132 & 0.342 & 0.903 \\
\hline $\mathrm{Na}^{+}$ & 0.216 & 0.151 & 0.970 & 0.151 & 0.652 & 0.656 \\
\hline $\mathrm{K}^{+}$ & $0.014^{*}$ & $0.000^{* * *}$ & 0.089 & $0.000^{* * *}$ & $0.000^{* * *}$ & 0.837 \\
\hline CEC & 0.507 & 0.718 & 0.084 & 0.718 & 0.581 & 0.811 \\
\hline BS & $0.008^{* *}$ & $0.005^{* *}$ & 0.946 & $0.005^{* *}$ & 0.359 & 0.503 \\
\hline BD & $0.037^{*}$ & 0.811 & 0.105 & 0.811 & $0.000^{* * *}$ & 0.393 \\
\hline $\mathrm{HC}$ & $0.026^{*}$ & $0.017^{*}$ & 0.199 & $0.017^{*}$ & 0.076 & 0.132 \\
\hline Sand & 0.360 & $0.000^{* * *}$ & $0.030^{*}$ & $0.000^{* * *}$ & 0.119 & 0.073 \\
\hline Silt & $0.012^{*}$ & $0.007^{* *}$ & $0.001^{* * *}$ & $0.007^{* *}$ & 0.964 & 0.441 \\
\hline Clay & $0.002^{* *}$ & $0.000^{* * *}$ & 0.077 & $0.000^{* * *}$ & $0.017^{*}$ & 0.091 \\
\hline PC1 & 0.458 & $0.000^{* * *}$ & $0.016^{*}$ & $0.000^{* * *}$ & 0.861 & 0.719 \\
\hline $\mathrm{PC} 2$ & $0.000^{* * *}$ & $0.020^{*}$ & 0.156 & $0.020^{*}$ & $0.000^{* * *}$ & 0.465 \\
\hline PC3 & 0.416 & $0.020^{*}$ & 0.281 & $0.020^{*}$ & $0.017^{*}$ & 0.272 \\
\hline PC4 & 0.521 & 0.154 & 0.322 & 0.154 & 0.095 & 0.124 \\
\hline
\end{tabular}

Th: thickness (cm); $\mathrm{pH}: \mathrm{pH}\left(\mathrm{H}_{2} \mathrm{O}\right)$; SOC: soil organic carbon $\left(\mathrm{g} \mathrm{kg}^{-1}\right)$; TN: total nitrogen $\left(\mathrm{g} \mathrm{kg}^{-1}\right)$; $/ \mathrm{N}: \mathrm{C}: \mathrm{N}$ ratio; exchangeable $\mathrm{Ca}^{2+}, \mathrm{Mg}^{2+}, \mathrm{Na}^{+}, \mathrm{K}^{+}\left(\mathrm{cmol} \mathrm{kg}^{-1}\right)$; CEC: cation exchange capacity $\left(\mathrm{cmol} \mathrm{kg}^{-1}\right)$; BS: base saturation (\%); BD: bulk density $\left(\mathrm{Mg} \mathrm{m}^{-3}\right)$; HC: hydraulic conductivity $\left(\mathrm{mm} \mathrm{h}^{-1}\right)$; sand, silt, clay (\%); PC1, PC2, PC3, PC4: factors PCA.

* Correlation is significant at $P<0.05$; ${ }^{* *}$ Correlation is significant at $P<0.01$; *** Correlation is significant at $P<0.001$.

respect to CT. This was caused by the high OM concentration in the Ap horizons. SOC in CT in the surface horizons was $<10 \mathrm{~g} \mathrm{~kg}^{-1}$ in CMs and LVs. These low SOC concentrations are due to the high mineralisation of $\mathrm{OM}$ and the absence of harvest residues after periods of drought (Hernanz et al., 2009). In agricultural soils, low SOC levels have a negative impact on soil physical properties and nutrient cycling, mainly associated with soil degradation (Romanya and Rovira, 2011). However, SOC in OF in the surface horizons was $>10 \mathrm{~g} \mathrm{~kg}^{-1}$ in CMs, LPs and RGs in the Los Pedroches Valley during the whole 20-year period. Similar results were reported by Álvarez et al. (2007) in OGs in OF. According to Aranda et al. (2011), OF could affect carbon retention under stable forms and could enable SOCS increase, contributing to agro-environmental benefits such as increased soil fertility, erosion prevention, etc.

\subsection{Management effect on soil organic carbon and nitrogen stocks}

A critical issue was to analyse the influence of management on SOC stock (SOCS). The highest total SOCS was found in LVs-OF (95.4 Mg ha ${ }^{-1}$ ) and the lowest in LPs-OF (42.77 $\mathrm{Mg} \mathrm{ha}^{-1}$ ) (Table 3). On average, the total SOCS for the main soil groups in Peninsular Spain (Rodríguez-Murillo, 2001) are $71.4 \mathrm{Mg} \mathrm{ha}^{-1}, 98.8 \mathrm{Mg} \mathrm{ha}^{-1}, 48.7 \mathrm{Mg} \mathrm{ha}^{-1}$ and $66 \mathrm{Mg} \mathrm{ha}^{-1}$ for CMs, LPs, RGs and LVs respectively and for soil used (OG) is $39.9 \mathrm{Mgha}^{-1}$. These differences in total SOCS for soil groups in Peninsular Spain and the studied soils are likely to be caused by soil thickness, as we used complete soil profiles and Rodriguez-Murillo (2001) used descriptions of soil profiles deeper than $1 \mathrm{~m}$.

Significant differences $(p<0.05)$ between SOCS under different management types were found in all soils. Therefore, the management system affected the total SOCS for the whole 20-year period. As for CMs and LVs, a higher total SOCS in OF than in CT was found. However, the trend was the opposite in LPs and RGs (more total SOCS in CT than OF). Similar results were obtained by Novara et al. (2012), attributing this phenomenon to the mixing of the upper soil layers during soil tillage. SOCS varies within the soil profile, with higher values in the topsoil in OF than in CT for $\mathrm{CMs}, \mathrm{LV}$ s and RGs. Similar values were found in LPs for OF versus CT (31.65 $\mathrm{Mg} \mathrm{ha}^{-1} \mathrm{CT}$; $\left.30.0 \mathrm{Mg} \mathrm{ha}^{-1} \mathrm{OF}\right)$. SOCS in 
the surface horizon varied between $34.95 \mathrm{Mg} \mathrm{ha}^{-1}$ for RGsOF and $23.22 \mathrm{Mg} \mathrm{ha}^{-1}$ for LVs-CT. Nevertheless, high values of SOC were found in less sandy soils (RGs and LVs) (Tables 2 and 3). By contrast, SOCS was higher in the subsoil (Bt and C horizons) in LVs-OF and RGs-CT than in the surface horizon. Therefore, two trends can be observed in the studied soils. In the first case, soils with low SOC, which could be explained by their texture (sandy soils) and which are associated with vegetation losses and unsustainable soil management practices. This situation favours a continuous impoverishment of the SOM content causing low soil productivity and derived in unsuitable chemical properties. In the second case, soils with high SOC values. This was especially important in clayey soils (RGs and LVs), and is related to the clay stabilisation process in the soil, increasing the clay content with respect to CMs and LPs. Similar results were obtained by Leifeld et al. (2005). This is especially important in the $\mathrm{Bt}$ and $\mathrm{C}$ horizons in LVs-OF and RGs-CT. These have a higher SOCS than the surface horizon. In this line, Shrestha et al. (2004) explained that this increase could be due to the translocation of carbon in the form of dissolved organic carbon, soil fauna activity, and/or the effects of deeprooting crops. Significant differences between horizons and soil types $(p<0.05)$ were found when the Ah horizon of LPs was not included in the analysis of management systems. Nevertheless, we found significant differences $(p<0.05)$ for total SOCS in all the studied soils.

As regards $\mathrm{N}$ stock (NS), the behaviour was similar to SOCS. The total NS showed significant differences $(p<0.05)$ in all soils with respect to management practices. When $\mathrm{N}$ was analysed, the results indicated a parallelism between $\mathrm{N}$ and SOC concentrations, which showed a positive $\mathrm{C}: \mathrm{N}$ relation (Table 4). According to this, the clay content slowed the SOC oxidation and could have a positive relationship between clay and nitrogen. A similar result was obtained by Sakin et al. (2010). Other studies state that N mineralisation decreases when the clay content increases (Côté et al., 2000). This effect was particularly important in CT ( $\mathrm{N}$ decreased when the clay content increased). In this line, McLauchlan (2006) explained that the aggregate formation increases and the potential $\mathrm{N}$ mineralisation decreases when the clay content increases in soil.

Melero et al. (2009) suggest that OF can increase SOC in longer experimental periods, which we can confirm because SOC and $\mathrm{N}$ stocks increased in OF during a long period (20 years).

\subsection{Stratification ratio of soil organic carbon}

In all soils, the SR of SOC increased with depth (Table 7). The SR of SOC of the surface with regard to depth [SR1] was higher in CT compared to OF, with the exception of RGs (SR1-RGs-CT 2.13; SR1-RGs-OF 3.33), in which the relation was the opposite due to the a low SOC concentration in $\mathrm{Ah} / \mathrm{C}$ in $\mathrm{CT}$. The [SR2] had a similar behaviour in
CMs and LVs. In LPs and RGs, this relation cannot be performed due to the lack of deeper horizons. Significant differences $(p<0.05)$ regarding the management system (by horizons) were found in CMs, LVs and RGs for SR of SOC. Many authors have shown SRs ranges from 1.1 to 1.9 for CT and between 2.1 and 4.1 for OF (Franzluebbers, 2002; Hernanz et al., 2009) for non-degraded soils. A good soil quality $(\mathrm{SR}>2)$ was observed when the SR was applied for SOC in both management systems with the exception of SR1-LVsOF (1.38). According to Franzluebbers (2005), the SR of SOC in depth under Mediterranean climatic conditions potentially affect the carbon incorporation in soils as the residue accumulation in the subsurface horizon has an effect on carbon incorporation. Also, the decomposition rates in deeper horizons are lower than in the upper soil horizons (Lorenz and Lal, 2005).

A critical issue was the reduction rates of SR of SOC in OF compared to CT in all soils except SR2-LVs and SR1RGs, which increased. This scenario implied a reduction of soil quality when OF is applied for a long term (20 years) in CMs and LPs. The SR of N showed a similar trend to SR of SOC. The SR of the $C: N$ ratio increased with depth with the exception of LVs-CT, which decreased with depth. Significant differences $(p<0.05)$ between management system (by horizons) were found in LVs and RGs for SR of N.

The SR of the $\mathrm{C}: \mathrm{N}$ ratio was normally higher in OF than in CT. Significant differences $(p<0.05)$ between management systems (by horizons) were found in CMs, LVs and RGs for SR of the $\mathrm{C}: \mathrm{N}$ ratio. This may be explained by a higher contribution of the residue relative to root inputs, leading to a higher soil $\mathrm{C}: \mathrm{N}$ ratio (Puget and Lal, 2005). Under $\mathrm{OF}$, the residue input could have been concentrated on the surface due to the straw soil surface coverage, leading to the stratification of the soil $\mathrm{C}: \mathrm{N}$ ratio. This slight change in the $\mathrm{C}: \mathrm{N}$ ratio suggests that the decomposition degree of SOC decreases toward the surface (Lou et al., 2012). This would involve little effect of the management system on the carbon accumulation in the soil. In this line, Balesdent and Balabane (1996) did not find any significant differences in SR, in a Geauga farm (Ohio).

In summary, the SR indexes in the studied soils showed three different results by soil type and management practices. In LPs, the management practices have little effect on carbon and $\mathrm{N}$ accumulation in the soil. In LVs and RGs, the management practices have an effect on carbon accumulation in OF: in LVs, the SR of SOC decreased in the topsoil but increased with depth. For RGs, land management changes increased the SR of SOC. Finally, in CMs a negative trend was observed, with the consequent SR decrease. Therefore, management practices affect SOC accumulation. The mean values of SR of SOC and TN were generally $>2$, with the exception of LVs-OT (SR1-SOC 1.38; SR1-N 1.28) (Table 7).

Furthermore, the SR of SOC provided information about the SOC effects in the top soil layer, which could affect SOC accumulation in the soil profile. This is important in 
Table 7. Stratification ratios of soil organic carbon concentration, total nitrogen concentration and C: N ratios in the Los Pedroches Valley (Mediterranean rangeland) in olive groves with conventional and organic farming. Data are mean $\pm \mathrm{SD}^{* *}$.

\begin{tabular}{|c|c|c|c|c|c|}
\hline Soil & Tillage & Relations & SOC-SR & N-SR & $\mathrm{C}: \mathrm{N}-\mathrm{SR}$ \\
\hline \multirow{2}{*}{$\mathrm{CM}$} & $\begin{array}{l}\mathrm{CT} \\
(n=32)\end{array}$ & $\begin{array}{l}\text { SR1 (Ap/Bw) } \\
\text { SR2 (Ap/C) }\end{array}$ & $\begin{array}{l}3.74 \pm 0.55 \mathrm{a}^{*} \\
3.82 \pm 0.15 \mathrm{a}^{*}\end{array}$ & $\begin{array}{l}2.45 \pm 0.37 \mathrm{a} \\
2.92 \pm 0.52 \mathrm{~b}\end{array}$ & $\begin{array}{l}1.52 \pm 0.11 \mathrm{a}^{*} \\
1.31 \pm 0.21 \mathrm{~b}^{*}\end{array}$ \\
\hline & $\begin{array}{l}\text { OF } \\
(n=18)\end{array}$ & $\begin{array}{l}\text { SR1 (Ap/Bw) } \\
\text { SR2 (Ap/C) }\end{array}$ & $\begin{array}{l}2.92 \pm 0.57 b \\
3.40 \pm 0.03 c\end{array}$ & $\begin{array}{l}2.51 \pm 0.57 \mathrm{a} \\
2.77 \pm 0.61 \mathrm{~b}\end{array}$ & $\begin{array}{l}1.16 \pm 0.08 \mathrm{c} \\
1.22 \pm 0.13 \mathrm{~d}\end{array}$ \\
\hline \multirow{2}{*}{ LV } & $\mathrm{CT}(n=12)$ & $\begin{array}{l}\text { SR1 (Ap/Bt) } \\
\text { SR2 (Ap/C) }\end{array}$ & $\begin{array}{l}2.30 \pm 0.35 \mathrm{a}^{*} \\
2.41 \pm 0.15 \mathrm{a}^{*}\end{array}$ & $\begin{array}{l}3.35 \pm 0.50 \mathrm{a}^{*} \\
2.03 \pm 0.28 \mathrm{~b}^{*}\end{array}$ & $\begin{array}{l}0.69 \pm 0.05 \mathrm{a}^{*} \\
1.19 \pm 0.11 \mathrm{~b}^{*}\end{array}$ \\
\hline & $\begin{array}{l}\mathrm{OF} \\
(n=8)\end{array}$ & $\begin{array}{l}\text { SR1 (Ap/Bt) } \\
\text { SR } 2(A p / C)\end{array}$ & $\begin{array}{l}1.38 \pm 0.65 b \\
2.92 \pm 0.46 c\end{array}$ & $\begin{array}{l}1.28 \pm 0.64 \mathrm{c} \\
2.85 \pm 0.48 \mathrm{~d}\end{array}$ & $\begin{array}{l}1.07 \pm 0.10 \mathrm{c} \\
1.03 \pm 0.21 \mathrm{c}\end{array}$ \\
\hline LP & $\begin{array}{l}\mathrm{CT}(n=18) \\
\mathrm{OF}(n=10)\end{array}$ & $\begin{array}{l}\text { SR1 }(\mathrm{Ah} / \mathrm{C}) \\
\text { SR1 }(\mathrm{Ah} / \mathrm{C})\end{array}$ & $\begin{array}{l}3.84 \pm 0.75 \mathrm{a} \\
3.69 \pm 0.80 \mathrm{a}\end{array}$ & $\begin{array}{l}3.41 \pm 0.53 \mathrm{a} \\
3.33 \pm 0.29 \mathrm{a}\end{array}$ & $\begin{array}{l}1.12 \pm 0.22 \mathrm{a} \\
1.11 \pm 0.17 \mathrm{a}\end{array}$ \\
\hline RG & $\begin{array}{l}\mathrm{CT}(n=8) \\
\mathrm{OF}(n=8)\end{array}$ & $\begin{array}{l}\text { SR1 }(\mathrm{Ah} / \mathrm{C}) \\
\text { SR1 }(\mathrm{Ah} / \mathrm{C})\end{array}$ & $\begin{array}{l}2.13 \pm 0.47 \mathrm{a}^{*} \\
3.33 \pm 0.85 \mathrm{~b}\end{array}$ & $\begin{array}{l}2.05 \pm 0.26 \mathrm{a}^{*} \\
2.83 \pm 0.38 \mathrm{~b}\end{array}$ & $\begin{array}{l}1.04 \pm 0.12 \mathrm{a}^{*} \\
1.16 \pm 0.18 \mathrm{~b}\end{array}$ \\
\hline
\end{tabular}

SOC-SR: Stratification ratio of soil organic carbon; N-SR: Stratification ratio of nitrogen; C: N-SR: Stratification ratio of the C: N ratio. CM: Cambisol; LP: Leptosol; RG: Regosol; LV: Luvisol. CT: Conventional tillage; OF: Organic farming.

$n=$ Sample size.

** Standard deviation.

* Significant differences $(P<0.05)$ between $\mathrm{CT}$ and $\mathrm{OF}$ treatments (by horizons).

Numbers followed by different lower-case letters within the same column are significant differences $(P<0.05)$

between depth, considering the same soil type.

the studied soils (with high values of SR of SOC and N). According to Jobbágy and Jackson (2000), when reviewing over 2700 soil profiles worldwide, vegetation and climate are associated with the vertical distribution of SOC, but climate and clay content are more decisive in SOC storage.

\section{Conclusions}

The study concludes that the management system (CT and OF) in CMs, LVs, RGs and LPs for a long period in OGs in the Los Pedroches Valley (Mediterranean rangelands) affected SOC content, exchangeable macroelements $\left(\mathrm{Ca}^{2+}\right.$ and $\mathrm{K}^{+}$), texture (sand and clay) and $\mathrm{N}$ content especially. With regard to the top soil, there were significant differences $(p<0.001)$ between soil types and management systems in OGs, affecting SOC content, exchangeable $\mathrm{K}^{+}$, BD, thickness, clay content and $\mathrm{pH}$.

The main feature of the studied soils was the low OM concentrations in depth, conditioned by a high sand content and by the climate (semi-arid Mediterranean conditions). OF had a positive impact on CMs and LVs (increasing the total SOCS and total NS) with respect to CT. Conversely, there was a negative impact in RGs and LPs. This was caused by the mixing of the upper soil layers during soil tillage. Also, this SOC reduction can be explain by a process of soil degradation and by the reduced OM input, as well as by the reduced physical protection of soil from erosion and the increased decomposition rate as a consequence of tillage. As for $\mathrm{N}$ concentrations, these were high in areas where the SOC was high, which showed a positive $\mathrm{C}: \mathrm{N}$ ratio relation.

The SR indicated a good soil quality. In all cases, the SR of SOC and N increased with depth. The SR of SOC comparing the surface and values in depth was greater in CT than in OT. Our results indicate a preferential accumulation of SOC in the surface horizons, influenced by Mediterranean climate. In subsurface horizons, the carbon decomposition rates are lower than in the upper soil layers. The SR of $\mathrm{C}: \mathrm{N}$ ratio increased with depth in some cases. Significant differences $(p<0.001)$ were found related to the management practices, which can be explained by a higher contribution of residue that implied a higher $\mathrm{C}: \mathrm{N}$ ratio. Under $\mathrm{OF}$ the $\mathrm{SOC}$ is concentrated on the soil surface. Also, the soil $\mathrm{C}: \mathrm{N}$ ratio is stratified. This slight change in the $\mathrm{C}: \mathrm{N}$ ratio suggests a decomposition degree of SOC, decreasing towards the surface. This indicated little effect of the management system on the carbon accumulation in the topsoil.

This research corroborates the need to analyse entire soil profiles under different management systems, because large amounts of SOC can be transported to deeper soil horizons in temperate climates, contributing to subsoil carbon storage.

Acknowledgements. This study was supported by the Regional Government of Andalusia through projects OG-019/07, OG018/06, OG-033/04 and OG-127/02.

Edited by: A. Jordán 


\section{References}

Álvarez, S., Soriano, M. A., Landa, B. B., and Gómez, J. A.: Soil properties in organic olive groves compared with that in natural areas in a mountainous landscape in southern Spain, Soil Use Manage., 23, 404-416, 2007.

Aranda, V., Ayora-Cañada, M. J., Domínguez-Vidal, A., MartínGarcía, J. M., Calero, J., Delgado, R., Verdejo, T., and GonzálezVila, F. J.: Effect of soil type and management (organic vs. conventional) on soil organic matter quality in olive groves in a semiarid environment in Sierra Mágina Natural Park (S Spain), Geoderma, 164, 54-63, 2011.

Balesdent, J. and Balabane, M.: Major contribution of roots to soil carbon storage inferred from maize cultivated soils, Soil Biol. Biochem., 28, 1261-1263, 1996.

Blanco-Canqui, H. and Lal, R.: No-tillage and soil-profile carbon sequestration: an on farm assessment, Soil Sci. Soc. Am. J., 72, 693-701, 2008.

Blake, G. R. and Hartge, K. H.: Particle density, in: Methods of soil analysis. Part I. Physical and mineralogical methods, edited by: Klute, A., Agronomy Monography no. 9, ASA, SSSA, Madison WI, USA, 377-382, 1986.

Bower, C. A., Reitemeier, R. F., and Fireman, M.: Exchangeable cation analysis of saline and alkali soil, Soil Sci., 73, 251-261, 1952.

Bradford, J. M. and Peterson, G. A.: Conservation tillage, in: Handbook of Soil Science, edited by: Sumner, M. E., CRC Press, Boca Raton, 247-269, 2000.

Bremner, J. M.: Total nitrogen, in: Methods of Soil Analysis: Chemical Methods, edited by: Sparks, D. L., Soil Science Society of America, Madison, WI, 1085-1086, 1996.

Bronick, C. J. and Lal, R.: Manuring and rotation effects on soil organic carbon concentration for different aggregate size fractions on two soils in northeastern Ohio, USA, Soil Till. Res., 81, 239252, 2005.

Calatrava, J., Barberá, G. G., and Castillo, V. M.: Farming practices and policy measures for agricultural soil conservation in semiarid Mediterranean areas: the case of Guadalentín basin in Southeast Spain, Land Degrad. Develop., 22, 58-69, 2011.

Calatrava-Leyva, J., Franco-Martínez, J. A., and González-Roa, M. C.: Analysis of the adoption of soil conservation practices in olive groves: the case of mountainous areas in southern Spain, Span. J. Agr. Res., 5, 249-258, 2007.

Castro, J., Fernández-Ondoño, E., Rodríguez, C., Lallena, A. M., Sierra, M., and Aguilar, J.: Effects of different olive-grove management systems on the organic carbon and nitrogen content of the soil in Jaén (Spain), Soil Till. Res., 98, 56-67, 2008.

Cerdà, A. and Doerr, S. H.: Soil wettability, runoff and erodibility of major dry Mediterranean land use types on calcareous soils, Hydrol. Process., 21, 2325-2336, 2007.

Cerdà, A., Lavee, H., Romero-Díaz, A., Hooke, J., and Montanarella, L.: Preface, Land Degrad. Develop., 21, 71-74, 2010.

Colombo, S., Hanley, N., and Calatrava, J.: Designing policy for reducing the off farm effects of soil erosion using choice experiments, J. Agr. Econ., 56, 81-95, 2005.

Conant, R. T., Easter, M., Paustian, K., Swan, A., and Williams, S.: Impacts of periodic tillage on soil C stocks: A synthesis, Soil Till. Res., 95, 1-10, 2007.

Corral-Fernández, R., Parras-Alcántara, L., and Lozano-García, B.: Stratification ratio of soil organic $\mathrm{C}, \mathrm{N}$ and $\mathrm{C}: \mathrm{N}$ in Mediter- ranean evergreen oak woodland with conventional and organic tillage, Agr. Ecosyst. Environ., 164, 252-259, 2013.

Côté, L., Brown, S., Paré, D., Fyles, J., and Bauhus, J.: Dynamics of carbon and nitrogen mineralization in relation to stand type, stand age and soil texture in the boreal mixedwood, Soil Biol. Biochem., 32, 1079-1090, 2000.

Diekow, J., Mielniczuk, J., Knicker, H., Bayer, C., Dick, D. P., and Kögel-Knabner, I.: Soil C and N stocks as affected by cropping systems and nitrogen fertilisation in a southern Brazil Acrisol managed under no-tillage for 17 years, Soil Till. Res., 81, 87-95, 2005.

Duchaufour, P. H.: Manual de Edafología, Editorial Toray-Masson, Barcelona, 1975.

ESYRCE: Encuesta sobre superficies y rendimientos. Ministerio de agricultura, alimentación y medio ambiente, Madrid, 2012.

FAO: Guidelines for soil description. Food and Agriculture Organization of the United Nations, Rome, Italy, 2006.

Fernández-Escobar, R., Marina, L., Sánchez-Zamora, M. A., García-Novelo, J. M., Molina-Soria, C., and Parra, M. A.: Longterm effects of $\mathrm{N}$ fertilization on cropping and growth of olive trees and on $\mathrm{N}$ accumulation in soil profile, Eur. J. Agronom., 31, 223-232, 2009.

Franzluebbers, A. J.: Soil organic matter stratification ratio as an indicator of soil quality, Soil Till. Res., 66, 95-106, 2002.

Franzluebbers, A. J.: Soil organic carbon sequestration and agricultural greenhouse gas emissions in the south eastern USA, Soil Till. Res., 83, 120-147, 2005.

Gómez, J. A., Sobrinho, T. A., Giráldez, J. V., and Fereres, E.: Soil management effects on runoff, erosion and soil properties in an olive grove of Southern Spain, Soil Till. Res., 102, 5-13, 2009.

González, I., Grau, J. M., Fernández, A., Jiménez, R., and González, M. R.: Soil carbon stocks and soil solution chemistry in Quercus ilex stand in Mainland Spain, Eur. J. Forest. Res., 131, 16531667, doi:10.1007/s10342-012-0623-8, 2012.

González, J. and Candás, M.: Materia orgánica de suelos bajo encinas, Mineralización de carbono y nitrógeno, Invest. Agrar., 7583, 2004.

Guitián, F. and Carballas, T.: Técnicas de Análisis de Suelos. Edit. Picro Sacro, Santiago de Compostela, España, 1976.

Hathaway-Jenkins, L., Sakrabani, R., Pearce, B., Whitmore, P., and Godwin, R.: A comparison of soil and water properties in organic and conventional farming systems in England, Soil Use Manage., 27, 133-142, 2011.

Hazelton, P. and Murphy, B.: Interpreting Soil Test Results: What Do All the Numbers Mean? CSIRO Publishing, Collingwood Victoria, Australia, 2007.

Hernanz, J. L., Sanchez-Giron, V., and Navarrete, L.: Soil carbon sequestration and stratification in a cereal/leguminous crop rotation with three tillage systems in semiarid conditions, Agr. Ecosyst. Environ., 133, 114-122, 2009.

Hontoria, C., Rodríguez-Murillo, J., and Saa, A.: Contenido de carbono orgánico en el suelo y factores de control en la España Peninsular, Edafología, 11, 149-155, 2004.

IOC, International Olive Council: The World Market in figures, OLIVAE, 117, 28-34, 2012.

IPCC, Intergovernmental Panel on Climate Change.: Good practice guidance for land use, land use change and forestry, in: IPCC/OECD/IEA/IGES, edited by: Penman, J., Gytarsky, M., 
Hiraishi, T., Krug, T., Kruger, D., Pipatti, R., Buendia, L., Miwa, K., Ngara, T., Tanabe, K., and Wagner, F., Hayama, Japan, 2003. IUSS Working Group WRB: World Reference Base for Soil Resources 2006, World Soil Resources Reports No. 103, 2nd edition, FAO, Rome, Italy, 2006

Jobbágy, E. G. and Jackson, R. B.: The vertical distribution of soil organic carbon and its relation to climate and vegetation, Ecol. Appl., 104, 423-436, 2000.

Lal, R., Delgado, J. A., Groffman, P. M., Millar, N., Dell, C., and Rotz, A.: Management to mitigate and adapt to climate change, J. Soil Water Conserv., 66, 276-285, 2011.

Leifeld, J., Bassin, S., and Fuhrer, J.: Carbon Stocks in Swiss agricultural soils predicted by Land-use. Soil charactetistics and altitude, Agr. Ecosyst. Environ., 105, 255-266, 2005.

López-Garrido, R., Madejón, E., Murillo, J., and Moreno, F.: Short and long term distribution with depth of soil organic carbon and nutrients under traditional and conservation tillage in a Mediterranean environment (southwest Spain), Soil Use Manage., 27, 177-185, 2011.

Lorenz, K. and Lal, R.: The depth distribution of organic soil carbon in relation to land use and management and the potential of carbon sequestration in subsoil horizons, Adv. Agron., 88, 35-66, 2005.

Lou, Y., Xu, M., Chen, X., He, X., and Zhao, K.: Stratification of soil organic $\mathrm{C}, \mathrm{N}$ and $\mathrm{C}: \mathrm{N}$ ratio as affected by conservation tillage in two maize fields of China, Catena, 95, 124-130, 2012.

Louwagie, G., Gay, S. H., Sammeth, F., and Ratinger, T.: The potential of European Union policies to address soil degradation in agriculture, Land Degrad. Develop., 22, 5-17, 2011.

Lozano-García, B. and Parras-Alcántara, L.: Short-term effects of olive mill by products on soil organic carbon, total $\mathrm{N}, \mathrm{C}: \mathrm{N}$ ratio and stratification ratios in a Mediterranean olive grove, Agr. Ecosyst. Environ., 165, 68-73, 2013a.

Lozano-García, B. and Parras-Alcántara, L.: Land use and management effects on carbon and nitrogen in Mediterranean Cambisols, Agr. Ecosyst. Environ., 179, 208-214, 2013b.

Lozano-García, B. and Parras-Alcántara, L.: Variation in soil organic carbon and nitrogen stocks along a toposequence in a traditional mediterranean olive grove, Land Degrad. Develop., in press, available online: in Wiley Online Library (wileyonlinelibrary.com), doi:10.1002/ldr.2284, 2014.

Lozano-García, B., Parras-Alcántara, L., and del Toro, M.: Effects of oil mill by-products on surface soil properties, runoff and soil losses in traditional olive groves in southern Spain, Catena, 85, 187-193, 2011.

MAGRAMA: Avances de superficies y producciones de cultivos. Madrid: Ministerio de Agricultura, Alimentación y Medio Ambiente, Madrid, 2012.

Marañón, T.: Agro-sylvo-pastoral systems in the Iberian Peninsula: Dehesas and Montados, Rangelands, 10, 255-258, 1988.

McLauchlan, K. K.: Effect of soil texture on soil carbon and nitrogen dynamic after cessation of agriculture, Geoderma, 136, 289-299, 2006.

Melero, S., López-Garrido, R., Murillo, J. M., and Moreno, F.: Conservation tillage: Short- and long-term effects on soil carbon fractions and enzymatic activities under Mediterranean conditions, Soil Till. Res., 104, 292-298, 2009.

Metson, A. J.: Methods of chemical analysis for soil survey samples. Soil Bureau bulletin, 12. Department of Scientific and In- dustrial Research and New Zealand Soil Bureau, Wellington, New Zealand, 1961.

Minitab.: Release 13. MINITAB Statistical Software, Minitab Inc., State College, PA, 2000.

Nelson, D. W. and Sommers, L. E.: Total carbon, organic carbon and organic matter. in: Methods of soil analysis, Part 2. Chemicaland microbiological properties, edited by: Page, A. L., Miller, R. H., and Keeney, D., Agronomy monograph, vol. 9, ASA and SSSA, Madison WI, 539-579, 1982.

Nerger, R., Rainer, M., Núñez, S., and Recio, J.: Presencia de carbonatos en suelos desarrollados sobre material granítico del Batolito de los Pedroches (Córdoba), in: Tendencias Actuales de la Ciencia del Suelo, edited by: Bellinfante, N. and Jordán, A., Sevilla, España, 2007.

Novara, A., La Mantia, T., Barbera, V., and Gristina, L.: Paired-site approach for studying soil organic carbon dynamics in a Mediterranean semiarid environment, Catena, 89, 1-7, 2012.

Parra-López, C., Groot, J. C. J., Carmona-Torres, C., and Rossing, W. A. H.: An integrated approach for ex-ante evaluation of public policies for sustainable agriculture at landscape level, Land Use Policy, 26, 1020-1030, 2009.

Parras-Alcántara, L., Díaz-Jaimes, L., and Lozano-García, B.: Organic farming affects $\mathrm{C}$ and $\mathrm{N}$ in soils under olive groves in Mediterranean areas, Land Degrad. Dev., in press, available online: in Wiley Online Library (wileyonlinelibrary.com), doi:10.1002/ldr.2231, 2013a.

Parras-Alcántara, L., Martín-Carrillo, M., and Lozano-García, B.: Impacts of land use change in soil carbon and nitrogen in a Mediterranean agricultural area (Southern Spain), Solid Earth, 4, 167-177, doi:10.5194/se-4-167-2013, 2013 b.

Parras-Alcántara, L., Díaz-Jaimes, L., and Lozano-García, B.: Management effects on soil organic carbon stock in Mediterranean open rangelands-treeless grasslands, Land Degrad. Develop., in press, available online: in Wiley Online Library (wileyonlinelibrary.com), doi:10.1002/ldr.2269, 2014a.

Parras-Alcántara, L., Díaz-Jaimes, L., Lozano-García, B., Fernández, P., Moreno, F., and Carbonero, M. D.: Organic farming has little effect on carbon stock in a Mediterranean dehesa (southern Spain), Catena, 113, 9-17, 2014b.

Paustian, K., Six, J., Elliott, E. T., and Hunt, H. W.: Management options for reducing $\mathrm{CO}_{2}$ emissions from agricultural soils, Biogeochemistry, 48, 147-163, 2000.

Puget, P. and Lal, R.: Soil organic carbon and nitrogen in a Mollisol in central Ohio as affected by tillage and land use, Soil Till. Res., 80, 201-213, 2005.

Pulido-Fernández, M., Schnabel, S., Lavado-Contador, J. F., Miralles, I., and Ortega, R.: Soil organic matter of Iberian open Woodland rangelands as influenced by vegetation cover and land management, Catena, 109, 13-24, 2013.

Recio, J. M., Corral, L., and Paneque, G.: Estudio de suelos en la Comarca de los Pedroches (Córdoba), Anal. Edaf. Agrob., 45, 989-1012, 1986.

Reynolds, W. D. and Elrick, D. E.: Determination of hydraulic conductivity using a tension infiltrometer, Soil Sci. Soc. Am. J., 55, 633-639, 1991.

Rodríguez-Entrena, M., Barreiro-Hurlé, J., Gómez-Limón, J. A., Espinosa-Goded, M., and Castro-Rodríguez, J.: Evaluating the demand for carbon sequestration in olive grove soils as a strat- 
egy toward mitigating climate change, J. Environ. Manage., 112, 368-376, 2012.

Rodríguez-Murillo, J. C.: Organic carbon content under different types of land use and soil in peninsular Spain, Biol. Fertil. Soils, 33, 53-61, 2001.

Romanya, J. and Rovira, P.: An appraisal of soil organic C content in Mediterranean agricultural soils, Soil Use Manage., 27, 321332, 2011

Ruiz, J. D., Pariente, S., Romero, A., and Martínez, J. F.: Variability of relationships between soil organic carbon and some soil properties in Mediterranean rangelands under different climatic conditions (South of Spain), Catena, 94, 17-25, 2012.

Sakin, E., Deliboran, A., Sakin, E. D., and Tutar, E.: Organic and inorganic carbon stock and balance of Adana city soils in Turkey, African J. Agr. Res., 5, 2737-2743, 2010.

Shrestha, B. M., Sitaula, B. K., Singh, B. R., and Bajracharya, R. M.: Soil organic carbon stocks in soil aggregates under different land use systems in Nepal, Nutr. Cycl. Agroecosys., 70, 201-213, 2004.
USDA: Soil survey laboratory methods manual, Soil survey investigation report No. 42, Version 4.0, USDA-NCRS, Lincoln, NE, 2004.

Wang, Y., Fu, B., Lü, Y., Song, C., and Luan, Y.: Local-scale spatial variability of soil organic carbon and its stock in the hilly area of the Loess Plateau, China, Quaternary Res., 73, 70-76, 2010.

Xu, M., Lou, Y., Sun, X., Wang, W., Baniyamuddin, M., and Zhao, K.: Soil organic carbon active fractions as early indicators for total carbon change under straw incorporation, Biol. Fertil. Soils, 47, 745-752, 2011.

Yamashita, T., Feiner, H., Bettina, J., Helfrich, M., and Ludwig, B.: Organic matter in density fractions of water-stable aggregates in silty soils: effect of land use, Soil Biol. Biochem., 38, 32223234, 2006.

Zdruli, P., Kapur, S., and Çelik, I.: Soils of the Mediterranean Region. Their characteristics, management and sustainable use, in: Sustainable land management learning from the past for the future, edited by: Kapur, S., Eswaran, H., and Blum, W. E. H., Springer-Verlag, Berlin, 2011. 